Jurnal geoedusains, Volume 1, Nomor 1, Juni 2020

\title{
Pengaruh Model Pembelajaran Cooperative Integrated Reading And Composition (Circ) Terhadap Hasil Belajar Geografi Kelas X di SMA Budi Luhur Samarinda
}

\author{
Gaudensius Jehamin $^{1^{\star}}$, Muliati Syam², lya 'Setyasih ${ }^{3}$ \\ Program Studi Pendidikan Geografi Universitas Mulawarman \\ *denyjehamin@gmail.com
}

\begin{abstract}
ABSTRAK
Pembelajaran Cooperative Integrated Reading and Composition (CIRC)menuntut peserta didik untuk dapat berperan aktif membangun sendiri pengetahuannya serta dapat meningkatkan pemahaman peserta didik terhadap materi. Penelitian ini bertujuan untuk mengetahui pengaruh model Cooperative Integrated Reading and Composition (CIRC) terhadap hasil belajar geografi Kelas X IPS SMA Budi Luhur Samarinda. Penelitian ini menggunakan penelitian kuantitatif jenis Quasye eksperimen design. Subjek penelitian ini adalah peserta didik kelas X IPS SMA Budi Luhur Samarinda dengan jumlah populasi 34 peserta didik. Teknik analisis data menggunakan $\mathrm{N}$-Gain. Berdasarkan hasil penelitian diperoleh rata rata nilai pre-test sebesar 51,17 dan rata-rata nilai post-test sebesar 87,35 . Hal ini menunjukan terdapat Cooperative Integrated Reading and Composition (CIRC) terhadap hasil belajar geografi Kelas X SMA Budi Luhur Samarinda.
\end{abstract}

Kata Kunci : Cooparative Integrated Reading and Composition, Hasil Belajar. SMA Budi Luhur

\section{The Effect of Cooperative Integrated Reading and Composition Learning Model (Circ) on Learning Outcomes of Class X Geography at Budi Luhur High School Samarinda}

\author{
Gaudensius Jehamin ${ }^{1 *}$, Muliati Syam², lya 'Setyasih ${ }^{3}$ \\ Geography Education Department Mulawarman University \\ "denyjehamin@gmail.com
}

\begin{abstract}
Cooperative Integrated Reading and Composition (CIRC) learning requires students to be able to play an active role in building their own knowledge and to increase students' understanding of the material. This study aims to determine the effect of the Cooperative Integrated Reading and Composition (CIRC) model on the learning geography outcomes of Class X IPS SMA Budi Luhur Samarinda. This study used quantitative research with type Quasi Design Experiments. The subject of this study is students of class X IPS SMA Budi Luhur Samarinda with a population of 34 Pengaruh Model Pembelajaran Cooperative...


students. The data analysis technique was used N-Gain. Based on the results of research data obtained an average pre-test value of 51.17 and an average post-test value of 87.35. The study shows that Cooperative Integrated Reading and Composition $(C I R C)$ in learning geography there is an outcomes of Class $X$ at SMA Budi Luhur Samarinda.

Keywords: Cooparative integrated Reading and Composition, Learning outcomes, Budi Luhur Senior High School

\section{Pendahuluan}

Pembelajaran geografi mencakup proses pemahaman kognitif, afektif, dan psikomotorik. Perkembangan dalam bidang geografi tidak mungkin terjadi bila tidak disertai dengan peningkatan mutu pendidikan geografi. Pembelajaraan geografi merupakan ilmu pengetahuan yang sangat penting untuk dipelajari. Berdasarkan hal tersebut dapat disimpulkan bahwa pada intinya ilmu geografi terpusat pada gejala geosfer dalam kaitan hubungannya dengan persebaran dan interaksi keruangan. Geografi merupakan salah satu mata pelajaran dalam kurikulum sekolah, baik di Indonesia maupun negara lainnya. Ini berarti bahwa konten geografi dinilai sangat penting bagi peserta didik, tidak hanya di Indonesia di berbagai negara di dunia. Mansfield (2002) mengemukakan bahwa sebagai berikut: konten geografi membantu peserta didik memahami negaranya dan negara lainnya di dunia.

Model pembelajaran (CIRC) merupakan model pembelajaran yang bertujuan untuk melatih kemampuan siswa secara terpadu antara membaca dan menemukan ide pokok suatu wacana/materi dan memberikan tanggapan secara tertulis. Melalui model tersebut pembelajaran Geografi yang tadinya dianggap membosankan dan banyak teori dapat dipelajari dengan mudah dan lebih menyenangkan. Pembelajaran dengan menggunakan model Cooperative Integrated Reading and Composition (CIRC) dilakukan dengan cara membentuk kelompok agar siswa mampu bekerjasama dengan teman satu kelompoknya untuk menemukan suatu ide pokok dan materi.Penerapan model pembelajaran CIRC ditujukan untuk menciptakan suasana belajar yang menyenangkan dan dapat berlangsung lebih interaktif dan komunikasi baik antara siswa dengan siswa maupun guru dengan siswa. Suasana yang menyenangkan diharapkan mampu meningkatkan hasil belajar siswa. 
Pembelajaran (CIRC) diharapkan siswa lebih kreatif dalam usaha memahami pelajaran yang disampaikan dan menumbuhkan rasa sosial yang tinggi. Siswa juga diharapkan akan termotivasi pada hasil secara teliti, karena bekerja dalam kelompok. Para siswa dapat memahami makna soal dan saling mengecek pekerjaannya satu sama lain dalam satu kelompok. Membantu siswa yang lemah dalam memahami pelajaran, serta dapat meningkatkan hasil belajar siswa khususnya pada mata pelajaran Geografi. Adapun yang menjadi tujuan dari penelitian ini 1) Untuk mengetahui hasil belajar siswa kelas X IPS SMA Budi Luhur Samarinda setelah mengikuti pembelajaran menggunakan model Cooperative Integrated Reading and Composition (CIRC), dan 2) Untuk mengetahui pengaruh model Cooperative Integrated Reading and Composition (CIRC) terhadap hasil belajar kelas X IPS SMA Budi Luhur Samarinda

\section{Metodologi}

Penelitian ini merupakan sebuah penelitian kuantitatif. Penelitian kuantitatif adalah penelitian dengan memperoleh data yang berbentuk angka atau data kualitatif yang diangkakan (Sugiyono, 2003). Penelitian ini dilakukan dengan desain One-Group Pretest-Posttest Designs yang merupakan jenis desain pre experimental menurut Sugiyono (2010). Desain penelitian ini hanya memiliki dua set data hasil pengukuran yaitu pretest $\left(\mathrm{O}_{1}\right)$ dan pengukuran posttest $\left(\mathrm{O}_{2}\right)$.

Populasi dalam penelitian ini adalah siswa kelas X IPS SMA Budi Luhur Samarinda semester ganjil tahun ajaran 2019/2020. Teknik pengambilan sampel menggunakan teknik purposive sampling, yaitu teknik pengambilan sampel yang anggota sampelnya dipilih atas dasar pertimbangan peneliti. Sedangkan teknik analisis datanya adalah sebagai berikut:

1) Analisis Hasil Belajar

Untuk mengetahui hasil belajar geografi siswa kelas XI IPS dapat langsung diketahui dari nilai postest yang diperoleh masing-masing siswa. Adapun langkahlangkah yang akan dilakukan peneliti adalah sebagai berikut: 
a. Memberikan Skor Mentah

Pemberian skor mentah pada jawaban siswa disesuaikan dengan bobot soal.

Pemberian skor mentah dilakukan dengan membandingkan jawaban siswa dengan kunci jawaban yang sudah ditentukan.

b. Menentukan Nilai Akhir

Nilai akhir siswa diproleh dengan menjumlahkan seluruh skor yang telah diperoleh dari skor mentah.

c. Nilai Rata-rata (mean)

Nilai rata-rata digunakan untuk mengetahui nilai hasil belajar dalam kelas dengan menggunakan rumus:

$$
\bar{X}=\frac{\sum X}{\boldsymbol{N}}
$$

Keterangan:

$$
\begin{aligned}
& \bar{X}=\text { Mean yang dicari } \\
& \Sigma X=\text { Jumlah dari skor (nilai) yang ada } \\
& \mathrm{N} \quad=\text { Jumlah siswa (Arikunto, 2009) }
\end{aligned}
$$

Pengelompokan katagori nilai untuk masing-masing siswa berdasarkan skala interpretasi nilai hasil belajar.

Tabel 1. Skala Interpretasi Nilai Hasil Belajar

\begin{tabular}{ccc}
\hline No & Interval Nilai & Keterangan \\
\hline 1. & $91 \leq X \leq 100$ & Baik Sekali \\
\hline 2. & $81 \leq X<90$ & Baik \\
\hline 3. & $71 \leq X<80$ & Cukup \\
\hline 4. & $61 \leq X<70$ & Kurang \\
\hline 5. & $0 \leq X<60$ & Kurang Sekali \\
\hline
\end{tabular}

2) Uji Normalitas Gain

Penelitian ini dilakukan dalam 5 kali pertemuan. Terdapat soal pretest dan posttest sebanyak 50 butir soal pilihan ganda. Data yang diperoleh melalui pretest dan posttest bertujuan untuk mengetahui pengaruh model pembelajaran Cooperative Intergrated Reading And Composition (CIRC) terhadap hasil belajar 
pada siswa kelas X IPS sebelum dan sesudah pembelajaran, yang dianalisis melalui Normalitas Gain (N-gain).

Gain adalah selisih antar nilai pretest dan posttest, gain menunjukkan peningkatan pemahaman atau penguasaan konsep siswa setelah pembelajaran diterapkan oleh guru. Uji gain merupakan sebuah uji yang bisa memberikan gambaran umum peningkatan skor hasil pembelajaran antara sebelum dan sesudah diterapkannya suatu model. ditinjau berdasarkan nilai $\mathrm{N}$-gain yang dinormalisasi (N-gain). Gain yang dinormalisasi (N-gain) dapat dihitung dengan persamaan. (Hake, 1999)

$$
N-\text { gain }=\frac{S_{\text {posttest }}-S_{\text {pretest }}}{S_{\text {maksimum }}-S_{\text {pretest }}}
$$

Keterangan:

$$
\begin{array}{ll}
N \text {-gain } & : \text { Keuntungan Atau Peningkatan } \\
S_{\text {pretest }} & : \text { Jumlah Skor Pretest } \\
S_{\text {posttest }} & : \text { Jumlah Skor Posttest } \\
S_{\text {maksimum }} & : \text { Jumlah Skor Maksimum (Idea }
\end{array}
$$

Setelah diketahui nilai $\mathrm{N}$-gain, kemudian dikategorikan peningkatan setiap siswa dalam menghitung rata-rata nilai $\mathrm{N}$-gain yang diperoleh masing-masing siswa sehingga diketahui peningkatan pemahaman siswa pada mata pelajaran geografi materi mitigasi bencana alam. Adapun kriteria nilai $\mathrm{N}$-gain menurut Hake (1999) adalah sebagai berikut

Tabel 2 Kategori Nilai N-Gain

\begin{tabular}{lc}
\multicolumn{1}{c}{ Nilai } & Keterangan \\
\hline$N$-gain $\geq 0,70$ & Tinggi \\
\hline $0,30<N$-gain $<0,70$ & Sedang \\
\hline$N$-gain $\leq 0,30$ & Rendah \\
\hline
\end{tabular}

\section{Hasil dan Pembahasan}

\section{Hasil Penelitian}

Hasil Belajar Model Pembelajaran Cooperative Integrated Reading And Composition (CIRC)

Deskripsi Hasil Data Pre-test Kelas X IPS 
Berdasarkan hasil data Pretest diketahui bahwa sebagian besar peserta didik padamkategori kurang sekali yaitu $0 \leq X \leq 60$ dengan nilai terendah 40 dan nilai tertinggi 60 dengan nilai rata-rata kelas sebesar 51,17 . Berikut adalah tabel penggolongan nilai pretest:

Tabel 3 Nilai Hasil Belajar Pretest Siswa Kelas X IPS

\begin{tabular}{lccc}
\hline No & Interval Nilai & Keterangan & Jumlah Siswa \\
\hline 1. & $91 \leq X \leq 100$ & Baik Sekali & 0 \\
\hline 2. & $81 \leq X \leq 90$ & Baik & 0 \\
\hline 3. & $71 \leq X \leq 80$ & Cukup & 0 \\
\hline 4. & $61 \leq X \leq 70$ & Kurang & 0 \\
\hline 5. $0 \leq X \leq 60$ & Kurang Sekali & 34 \\
Jumlah & & 34 \\
\hline
\end{tabular}

Deskripsi Hasil Data Post Test Kelas X IPS

Berdasarkan hasil Post test diketahui bahwa sebagian besar peserta didik nilai peserta didik berada pada kategori baik dan baik sekali yaitu antara $75 \leq X \leq 95$ dengan nilai terendah 75 dan nilai tertinggi 95 dengan nilai rata-rata sebesar 87, 35 . Berikut adalah tabel penggolongan nilai post test:

Tabel 4 Nilai Hasil Belajar Post Test Siswa Kelas X IPS No Interval Nilai Keterangan Jumlah siswa

\begin{tabular}{llll}
\hline 1. & $91 \leq X \leq 100$ & Baik Sekali & 29 \\
\hline 2. & $81 \leq X \leq 90$ & Baik & 5 \\
\hline 3. & $71 \leq X \leq 80$ & Cukup & 0 \\
\hline 4. & $61 \leq X \leq 70$ & Kurang & 0 \\
\hline 5. & $0 \leq X \leq 60$ & Kurang Sekali & 0 \\
Jumlah & & 34 \\
\hline
\end{tabular}

Pengaruh Model Pembelajaran Cooperative Integrated Reading And Composition (CIRC) Terhadap Hasil Belajar Geografi Kelas X di SMA Budi Luhur Samarinda

Berdasarkan hasil penelitian diketahui bahwa distribusi frekuensi data nilai ratarata post-test sebsar 87,35 . Hal ini menunjukkan adanya pengaruh model pembelajaran Cooperative Integrated Reading And Composition (CIRC) terhadap hasil belajar peserta didik adapun nilai rata-rata pre-test 51,17 dan nilai rata-rata N Gain Score 35,88 . 
Tabel 5 Rata-Rata Nilai Gain Score Model (CIRC)

\begin{tabular}{llll}
\hline & \multicolumn{3}{c}{ Nilai Rata-Rata } \\
\cline { 2 - 4 } Kelas & Pre-Test & Post-Test & Gain Score \\
\hline $\mathrm{X}$ & 51,17 & 87,35 & 35,88 \\
\hline
\end{tabular}

Berdasarkan data N-Gains Score tersebut, termasuk kategori tinggi karena lebih 30 dan berada pada ketegori baik.

\section{Pembahasan}

Proses pembelajaran dimulai dari kegiatan awal yaitu peneliti membuka pembelajaran dengan mempersiapkan siswa untuk belajar dan memberikan orientasi tentang materi pembelajaran yang akan dibahas dengan menggunakan model (CIRC) terhadap hasil belajar siswa.. Kemudian masuk ke tahap kegiatan inti pembelajaran yaitu klasifikasi masalah dengan menyampaikan tujuan pembelajaran terlebih dahulu, dimana peneliti menyajikan masalah yang menuntut siswa untuk bisa menyelesaikan permasalahan sebelumnya siswa diberikan pengantar materi yang akan dibahas dan dibantu dengan media LCD yang berkaitan dengan pelajaran geografi pada materi bumi sebagai ruang kehidupan, dilanjutkan dengan mengidentifikasi masalah dimana siswa diberi Lembar Kerja Peserta Didik (LKPD) berupa soal dan gambar tentang permasalahan yang ada. Pada tahap ini siswa melakukan percobaan atau mengemukakan berbagai macam argument dalam proses pembelajaran baik secara individu maupun kelompok.

Selanjutnya menarik kesimpulan berdasarkan hasil analisis tentang jawaban peserta didik, proses pembelajaran diakhri dengan tahap penutup yaitu siswa saling memberikan umpan balik hasil evaluasi pembelajaran yang telah dicapai. Dengan demikian dapat diperoleh data pengaruh hasil belajar geografi dengan menggunakan model pembelajaran Cooperative Integrated Reading And Composition (CIRC) terhadap hasil belajar geografi pada siswa kelas X IPS SMA Budi Luhur Samarinda. Berikut akan dibahas mengenai uraian dari data hasil penelitian. 


\section{Hasil Belajar Geografi}

Berdasarkan hasil penelitian diketahui bahwa nilai rata-rata pretest adalah sebesar 51,17, dan hal ini menunjukan bahwa nilai rata-rata peserta didik belum mencapai kriteria ketuntusan. Berbeda dengan penelitian sebelumnya yang dilakukan Permana (2015), diamana ada pengaruh hasil belajar dengan menggunakan model yang sama yaitu model Cooperative Integrated Reading And Composition (CIRC) sedangkan hasil belajar peserta didik memperoleh nilai rata-rata pos-test sebesar 87,35 dengan kategori baik.

Pengaruh model pembelajaran Cooperative Integrated Reading And Composition (CIRC) terhadap hasil belajar geografi kelas X di SMA Budi Luhur Samarinda

Berdasarkan nilai uji $\mathrm{N}$-gain diketahui bahwa rata-rata nilai pre test siswa kelas X IPS sebesar 51,17 . Hal ini menunjukkan bahwa nilai rata-rata siswa belum mencapai Kriteria Ketuntasan Minimal, sedangkan analisis $\mathrm{N}$-gain data post test diperoleh nilai rata-rata sebesar 87,35 hal ini menunjukkan bahwa nilai yang diperoleh peserta didik sudah mencapai kriteria ketuntasan dan mengalami peningkatan hasil belajar. Artinya bahwa ada pengaruh setelah mengikuti pembelajaran dengan menggunakan model Cooperative Integrated Reading And Composition (CIRC) terhadap hasil belajar peserta didik. Hasil analisis $\mathrm{N}$-Gain setahui pula penggunaan model Cooperative Integrated Reading And Composition (CIRC) dapat meningkatkan pemahaman peserta didik kelas X IPS SMA Budi Luhur Samarinda.

\section{Kesimpulan}

Berdasarkan hasil penelitian dan pembahasan mengenai pengaruh model pembelajaran Cooperative Integrated Reading And Composition (CIRC) terhadap hasil belajar geografi pada siswa kelas X IPS di SMA Budi Luhur Samarinda pada materi tentang bumi sebagai ruang kehidupan maka dapat disimpulkan bahwa: 
1. Hasil belajar geografi siswa memperoleh nilai pre test rata-rata 51,17 dengan kategori kurang sekali dan nilai pos test memperoleh nilai rata-rata 87,35 dengan kategori baik.

2. Pengaruh model pembelajaran Cooperative Integrated Reading And Composition (CIRC) yaitu persentase nilai $\mathrm{N}$-gain $58,82 \%$ kategori tinggi, dan $41,17 \%$ kategori sedang, dan terdapat pengaruh yang valid dan signifikan model pembelajaran Cooperative Integrated Reading And Composition (CIRC) dapat meningkatkan hasil belajar siswa pada mata pelajaran geografi materi tentang bumi sebagai ruang kehidupan

\section{Daftar Pustaka}

Arikunto, Suharsimi. 2013. Prosedur Penelitian Suatu Pendekatan Praktik. Jakarta: Bumi Aksara.

Hake 1999, 2010. Belajar dan Pembelajaran. Bandung: Alfabeta, Permana 2015. Strategi Pembelajaran Geografi. Yogyakarta: Penerbit Ombak. Sugiyono, 2003. Strategi Pembelajaran. Falah Production. Bandung: CV Alfabeta. Slameto. 2003. Belajar dan Faktor-faktor yang Mepengaruhinya. Jakarta: Rineka Cipta. Slavin, Robert E. 2005. Cooperative Learning. Bandung: Nusa Media, Mansfield (2002). Mengemukakan ilmu Pembelajaran. Semarang Sugiyono. 2010. Metodologi Penelitian Pendidikan. Bandung: CV Alfabeta. 